\title{
Binding of haemin by the fish pathogen Photobacterium damselae subsp. piscicida
}

\author{
Ana do Vale ${ }^{1,2, *}$, Beatriz Magariños ${ }^{1}$, Jesús L. Romalde ${ }^{1}$, Manuel L. Lemos ${ }^{3}$, \\ Anthony E. Ellis ${ }^{4}$, Alicia E. Toranzo ${ }^{1}$ \\ ${ }^{1}$ Departamento de Microbiología y Parasitología, Facultad de Biología, Universidad de Santiago de Compostela, \\ 15782 Santiago de Compostela, Spain \\ ${ }^{2}$ Institute for Molecular and Cell Biology, University of Porto, Rua do Campo Alegre 823, 4150-180 Porto, Portugal \\ ${ }^{3}$ Departamento de Microbiología y Parasitología, Facultad de Ciencias, Universidad de Santiago de Compostela, \\ Campus de Lugo, 27002 Lugo, Spain \\ ${ }^{4}$ Marine Laboratory, Fisheries Research Services, PO Box 101, Victoria Rd, Aberdeen AB11 9DB, Scotland, UK
}

\begin{abstract}
Whole cells of virulent (DI 21 and B 51) and avirulent (ATCC 29690 and EPOY 8803-II) strains of Photobacterium damselae subsp. piscicida, grown under iron-supplemented or ironrestricted conditions, were able to bind haemin. Iron limitation resulted in an increased binding of haemin by DI 21, B 51 and ATCC 29690 cells but did not affect the haemin-binding ability of the EPOY 8803-II cells. Proteinase K treatment of whole cells markedly reduced the binding of haemin, indicating that protein receptors located at the cell surface are involved in the binding. This was confirmed by the observation that isolated total as well as outer membrane proteins from all the strains, regardless of the iron levels of the media, were able to bind haemin, with the outer membranes showing the strongest binding. Haemin binding by membrane protein extracts was not affected by heat treatment but was almost completely abolished by Proteinase K treatment, suggesting the presence of thermostable protein receptors for haemin. The capsular polysaccharide also appears to play a minor role in binding of haemin. It was concluded that constitutive as well as inducible mechanisms of haemin binding occur in $P$. damselae subsp. piscicida. These mechanisms would rely mainly upon the direct interaction between the haemin molecules and surface-exposed outer membrane protein receptors.
\end{abstract}

KEY WORDS: Photobacterium damselae subsp. piscicida $\cdot$ Haemin binding $\cdot$ Iron acquisition Resale or republication not permitted without written consent of the publisher

\section{INTRODUCTION}

Bacteria have a nutritional need for iron and must obtain it from the environment. One of the host defence mechanisms against infection is the ability to reduce free extracellular iron to concentrations below the minimum required to support the growth of bacteria (Martínez et al. 1990). Although there is plenty of iron present in the infected host, the amount of free iron, which is readily available to the infecting bacte-

*E-mail: avale@ibmc.up.pt ria, is extremely small. This is due to the low solubility of $\mathrm{Fe}^{3+}$ at physiological $\mathrm{pH}$ and to its sequestration by intracellular and extracellular high affinity ironbinding proteins (Bullen 1981, Griffiths 1987, Martínez et al. 1990, Payne 1993, Weinberg 1993, Schryvers \& Stojiljkovic 1999).

Pathogenic bacteria have developed several mechanisms to acquire iron in order to overcome the ironwithholding capacity of the host. One involves the synthesis of siderophores and specific transport systems for the uptake of the iron-loaded siderophores into the cell (Otto et al. 1992, Moeck \& Coulton 1998). Other mechanisms rely on the interaction between specific 
microbial receptors and host transferrin or haemcontaining compounds (Otto et al. 1992, Lee 1995).

Photobacterium damselae subsp. piscicida (formerly Pasteurella piscicida) is the causative agent of fish pasteurellosis, a disease known for a long time to affect wild and cultured marine fish in the USA and Japan (Kitao 1993). Since 1990, outbreaks of fish pasteurellosis have occurred in various European countries, causing important economic losses in gilthead seabream Sparus aurata and sea bass Dicentrarchus labrax L. cultures (Magariños et al. 1996b, Romalde \& Magariños 1997).

It has been reported that iron plays a role in the virulence of Photobacterium damselae subsp. piscicida (Magariños et al. 1994). However, the mechanisms by which this fish pathogen can acquire iron from the host are not clearly understood. It has been shown that $P$. damselae subsp. piscicida is able to obtain iron bound to human transferrin by means of a siderophoremediated mechanism (Magariños et al. 1994). Furthermore, it was shown that this bacterium is able to utilise haemin and haemoglobin as the sole iron source in vitro and that haemin and haemoglobin, as well as ferric ammonium citrate, injected intraperitoneally into the fish several hours before experimental infection increase the lethality of this microorganism (Magariños et al. 1994).

The aims of the present work were to investigate whether Photobacterium damselae subsp. piscicida is able to bind haemin and to elucidate the nature of the haemin-binding mechanisms.

\section{MATERIALS AND METHODS}

Bacterial strains and growth conditions. Four strains of Photobacterium damselae subsp. piscicida (DI 21, B 51, ATCC 29690 and EPOY 8803-II) were used in this study. The origin and virulence of the strains are listed in Table 1. In some experiments, Escherichia coli HB

Table 1. Origin and virulence of the Photobacterium damselae subsp. piscicida isolates used in the present study

\begin{tabular}{|c|c|c|c|}
\hline Strain & $\overline{\text { Source }}$ Origin & Donor $^{a}$ & $\begin{array}{l}\text { Virulence } \\
\text { for fish }^{\mathrm{b}}\end{array}$ \\
\hline DI 21 & Sparus aurata, Spain & Laboratory collection $^{\mathrm{c}}$ & + \\
\hline В 51 & Dicentrarchus labrax, Spain & J. Borrego & + \\
\hline EPOY 8803-II & Epinephelus akaara, Japan & K. Muroga & - \\
\hline ATCC 29690 & Seriola quiqueradiata, Japan & ATCC & - \\
\hline \multicolumn{4}{|c|}{$\begin{array}{l}\text { aDonor addresses: ATCC (American Type Culture Collection), Rockville, } \\
\text { Maryland; K. Muroga, Faculty of Applied Biological Science, Hiroshima } \\
\text { University, Hiroshima, Japan; J. Borrego, Departamento de Microbiología, } \\
\text { Facultad de Ciencias, Universidad de Málaga, Málaga, Spain } \\
\text { bata obtained from Magariños et al. (1994) } \\
\text { 'Departamento de Microbiología y Parasitología, Facultad de Biología, Uni- } \\
\text { versidad de Santiago de Compostela, } 15782 \text { Santiago de Compostela, Spain }\end{array}$} \\
\hline
\end{tabular}

101 and Vibrio anguillarum 775 were used as controls. $P$. damselae subsp. piscicida and $V$. anguillarum strains were routinely cultured at $25^{\circ} \mathrm{C}$ in tryptic soy broth (TSB) (Pronadisa) or on tryptic soy agar (TSA) supplemented with $\mathrm{NaCl}$ to a final concentration of $1 \%(\mathrm{w} / \mathrm{v})$ (TSB-1 and TSA-1, respectively). E. coli was cultured in TSB or on TSA at $37^{\circ} \mathrm{C}$. All strains were stored frozen at $-70^{\circ} \mathrm{C}$ in the appropriate broth media supplemented with $15 \%$ (v/v) glycerol.

Iron-limited conditions were obtained by adding the iron chelator ethylenediamine-di-(o-hydroxyphenylacetic acid) (EDDHA, Sigma) to the TSB-1 at a final concentration of $100 \mu \mathrm{g} \mathrm{ml}^{-1}$. Iron-supplemented conditions were obtained by addition of $\mathrm{FeCl}_{3}$ to the culture medium at a final concentration of $10 \mu \mathrm{M}$.

Preparation of total and outer membrane proteins. Bacterial strains were grown for 24 to $48 \mathrm{~h}$ in TSB-1 supplemented either with EDDHA or $\mathrm{FeCl}_{3}$ and were then harvested by centrifugation at $10000 \times g$ for $10 \mathrm{~min}$ at $4^{\circ} \mathrm{C}$. Total and outer membrane proteins were extracted as previously described (Toranzo et al. 1983). To obtain outer membrane proteins, total membranes were subjected to treatment with $3 \%(\mathrm{w} / \mathrm{v})$ sodium lauroyl sarcosinate (sarcosyl, Sigma) to selectively solubilise inner membranes (cytoplasmic membranes). The outer membranes were then collected by centrifugation. Total and outer membrane proteins were stored at $-20^{\circ} \mathrm{C}$. The protein concentrations were determined using a Bio-Rad protein assay kit, with bovine serum albumin as standard.

Haemin-binding assays. Bovine haemin (Sigma) was dissolved in $10 \mathrm{mM} \mathrm{NaOH}$ to a final concentration of $1 \mathrm{mg} \mathrm{ml}^{-1}$ before use. Haemin binding was assayed using 2 different procedures.

(1) Solid-phase dot blot assay. For the whole cell assay, bacteria were cultured for 24 to $48 \mathrm{~h}$ under ironlimited or iron-supplemented conditions and harvested by centrifugation at $4000 \times g$ for $5 \mathrm{~min}$. They were then washed in Tris-buffered saline (TBS) (50 mM Tris-HCl supplemented with $0.9 \% \mathrm{NaCl}, \mathrm{pH} 8.0)$ and resuspended to an optical density (OD) of 1.0 at $580 \mathrm{~nm}$. A $30 \mu \mathrm{l}$ volume of the cell suspension was placed onto nitrocellulose membranes $(0.45 \mu \mathrm{m}$ pore size; Schleicher \& Schuell) in a dot blot manifold. The binding of haemin was assayed as previously described (Mazoy \& Lemos 1996). Briefly, after immobilisation the membranes were air dried, blocked with gelatin ( $2 \%$ in TBS), incubated for $2 \mathrm{~h}$ with haemin (10 $\mu \mathrm{M}$ in TBS), immersed for $30 \mathrm{~min}$ in $12.5 \%$ trichloroacetic acid, washed in distilled water and stained with 3,3'-dimeth- 
oxybenzidine (DMB, Sigma). The DMB solution (50 mg of DMB in $15 \mathrm{ml}$ of distilled water) was freshly prepared just before staining, and after the solution was stirred for $15 \mathrm{~min}, 5 \mathrm{ml}$ of a $0.5 \mathrm{M}$ sodium citrate buffer (pH 4.4) and $100 \mu \mathrm{l}$ of $30 \% \mathrm{H}_{2} \mathrm{O}_{2}$ were added. After staining for 1 to $3 \mathrm{~min}$, the membrane was washed with water to clear the background.

(2) Binding in liquid. The protocol used to detect binding of haemin in liquid was similar to that previously described (Hirst et al. 1994). Bacterial strains were cultured for 24 to $48 \mathrm{~h}$ under iron-supplemented and iron-limited conditions, collected by centrifugation at $4000 \times g$ for $5 \mathrm{~min}$ and washed in phosphate-buffered saline ( $\mathrm{PBS}_{i} \mathrm{pH}$ 7.4). They were then resuspended in the same buffer and adjusted to an OD of 0.8 at $580 \mathrm{~nm}$. Bovine haemin was added to the bacterial suspensions at a final concentration of 20 to $25 \mathrm{\mu g} \mathrm{ml}^{-1}$ followed by incubation at $25^{\circ} \mathrm{C}$ for $60 \mathrm{~min}$. At intervals, bacteria were pelleted in an Eppendorf centrifuge. Binding of haemin was determined by assaying spectrophotometrically at $400 \mathrm{~nm}$ the residual compound in the supernatant. The amount of residual haemin was then compared with a standard curve of haemin in PBS, and the amount of compound bound by the bacteria was then determined by subtraction. To determine whether haemin binding was protein associated, bacterial suspensions were incubated with $500 \mathrm{~g} \mathrm{ml}^{-1}$ of Proteinase K (Sigma) in PBS for $1 \mathrm{~h}$ at $37^{\circ} \mathrm{C}$ before liquid-binding assays. Bacterial suspensions not preincubated with the enzymes were used as controls.

Competitive binding assays. Competitive binding assays were performed with bacteria cultured under iron-limited conditions to investigate whether different haem compounds shared the same binding site or receptor. Bovine haemoglobin and protoporphyrin IX (both from Sigma) were dissolved, to a final concentration of $1 \mathrm{mg} \mathrm{ml}^{-1}$, in distilled water or $10 \mathrm{mM} \mathrm{NaOH}$, respectively. Bacteria were incubated in the presence of $30 \mu \mathrm{g} \mathrm{ml}^{-1}$ bovine haemoglobin or protoporphyrin IX for $1 \mathrm{~h}$ at $25^{\circ} \mathrm{C}$. Bacteria were then pelleted by centrifugation and resuspended in PBS containing $30 \mu \mathrm{g}$ $\mathrm{ml}^{-1}$ haemin. The amount of haemin bound over a 60 min period was determined spectrophotometrically, as described above. Cells not pre-incubated with the competitors were used as controls.

Haemin binding by bacterial membrane protein extracts. To evaluate the binding of haemin by membrane protein extracts, volumes of $20 \mu \mathrm{l}$ of either total or outer membrane proteins, containing 100, 10 and $1 \mathrm{\mu g} \mathrm{ml}^{-1}$ of protein in distilled water, were immobilised on nitrocellulose membranes, which were then blocked with gelatine and incubated with haemin, immersed in $12.5 \%$ trichloroacetic acid, washed in distilled water and stained with DMB, as described above. Vibrio anguillarum 775 was used as a positive control and Escherichia coli HB101 as a negative control. The effect of heat or protease treatment on haemin binding by protein extracts was evaluated by incubating bacterial total and outer membrane proteins, adjusted to a concentration of $100 \mathrm{~g} \mathrm{ml}^{-1}$ in distilled water, either for $10 \mathrm{~min}$ at $100^{\circ} \mathrm{C}$ or with Proteinase K (added to a final concentration of $100 \mathrm{\mu g} \mathrm{ml}^{-1}$ ) for $45 \mathrm{~min}$ at $37^{\circ} \mathrm{C}$. The samples were then loaded onto a nitrocellulose membrane ( $2 \mu \mathrm{g}$ per band) and subjected to a dot blot assay to evaluate the binding of haemin. Untreated samples were used as controls.

Haemin binding by purified capsular polysaccharide. Purified capsular polysaccharide from the pathogenic strain DI 21 was previously obtained (Bonet et al. 1994) and maintained, lyophilised, until used. This capsular material was resuspended in TBS to a final concentration of $1 \mathrm{mg} \mathrm{ml}^{-1}$. The suspension was double diluted, until a concentration of $125 \mu \mathrm{g} \mathrm{m}^{-1}$ was obtained. From each concentration, $30 \mu \mathrm{l}$ was immobilised on a nitrocellulose membrane and tested for the ability to bind haemin, using the dot blot assay. To investigate the effect of heat or protease treatment on the binding of haemin by purified capsular polysaccharide, the samples, resuspended in TBS at a concentration of $1 \mathrm{\mu g} \mathrm{ml}^{-1}$, were incubated either at $100^{\circ} \mathrm{C}$ for $10 \mathrm{~min}$ or for $30 \mathrm{~min}$ at $37^{\circ} \mathrm{C}$ with Proteinase $\mathrm{K}$ (final concentration of $100 \mu \mathrm{g} \mathrm{ml}^{-1}$ ). Treated suspensions were diluted as above and subjected to the dot blot assay to detect binding of haemin. Untreated samples were used as controls.

Statistical analysis. The results of the liquid binding assays were analysed by applying Student's $t$-test. The differences were considered significant when $p<0.05$. The data are presented as mean \pm standard error.

\section{RESULTS}

\section{Haemin binding by whole cells}

All the virulent and non-virulent strains tested, regardless of culture conditions, were able to bind haemin (Fig. 1a). However, it was found that when cells from the DI 21, B 51 (virulent) and ATCC 29690 (non-virulent) strains were grown under iron-limited conditions, the affinity for the compound increased greatly. Although this difference was observed using both methods, it was more evident when the assay in liquid was performed $(p<0.005)$. Fig. $1 \mathrm{~b}$ compares the haemin-binding abilities of the virulent strain DI 21 under iron-restricted conditions with those under ironsupplemented conditions in the liquid assay. In contrast, growth under iron-limited conditions did not change the haemin-binding levels of the non-virulent EPOY 8803-II cells (Fig. 1c). 


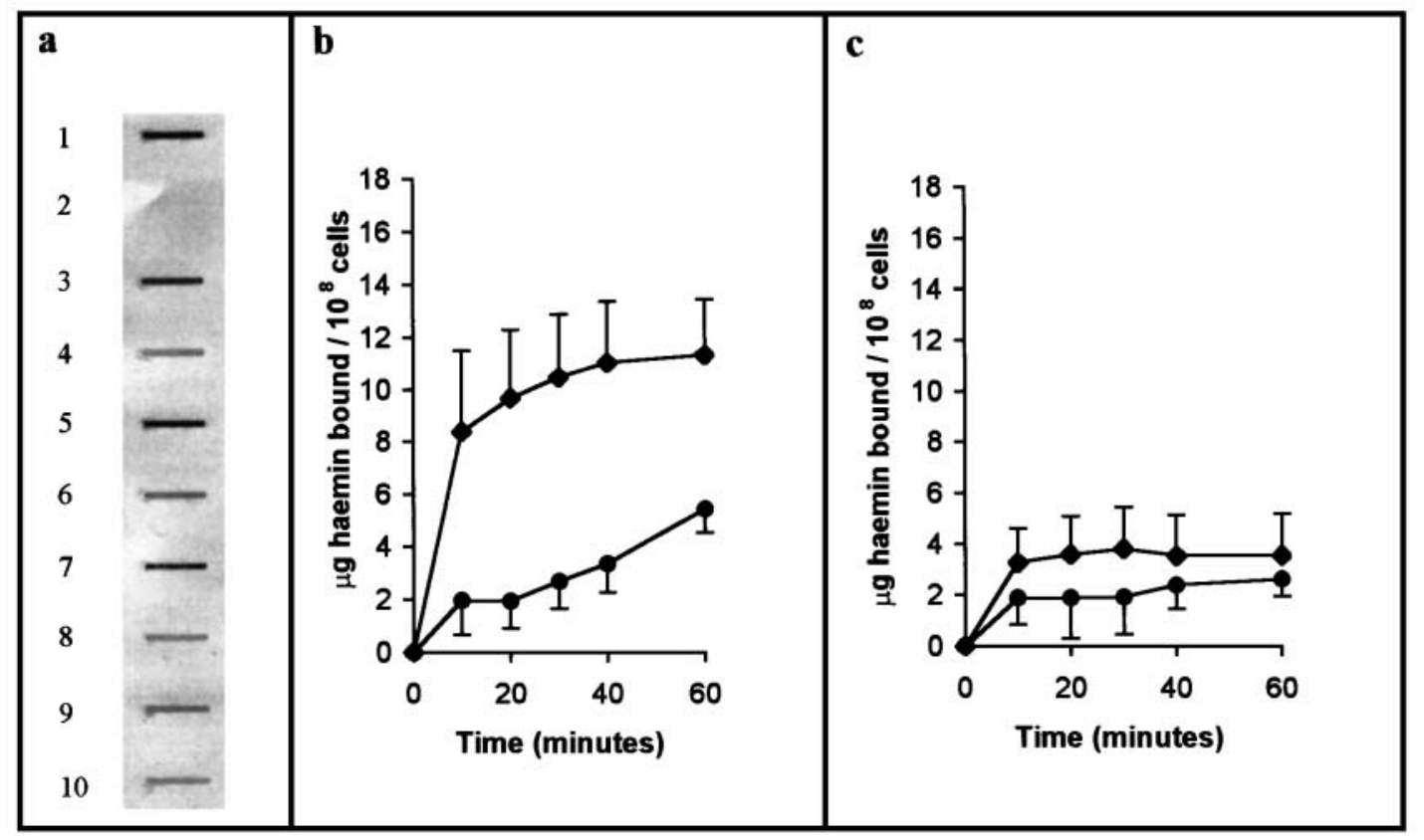

Fig. 1. Binding of haemin by Photobacterium damselae subsp. piscicida whole cells. (a) P. damselae strain DI 21(lanes 3, 4), B 51 $(5,6), \operatorname{ATCC} 29690(7,8)$ and EPOY 8803-II $(9,10)$ cells cultured under iron-restricted (tryptic soy broth with NaCL [TSB-1] + ethylenediamine-di-(o-hydroxyphenyl-acetic acid) [EDDHA]) $(3,5,7,9)$ or iron-supplemented (TSB-1+Fe) $(4,6,8,10)$ conditions were tested by the dot blot assay. Vibrio anguillarum 775 (1) and Escherichia coli HB101 (2) were used as positive and negative controls, respectively. Binding of haemin by P. damselae subsp. piscicida (b) strain DI 21 or (c) strain EPOY 8803-II. Cells grown under iron-restricted $(\bullet)$ or iron-supplemented $(\bullet)$ conditions were tested by the liquid binding assay

\section{Haemin binding by bacterial membrane protein extracts}

Using the dot blot assay, it was found that both total and outer membrane proteins from iron-supplemented or from iron-restricted Photobacterium damselae subsp. piscicida cells were able to bind haemin. With the same amount of protein, stronger binding to outer membrane proteins than to total proteins was detected (Fig. 2a).

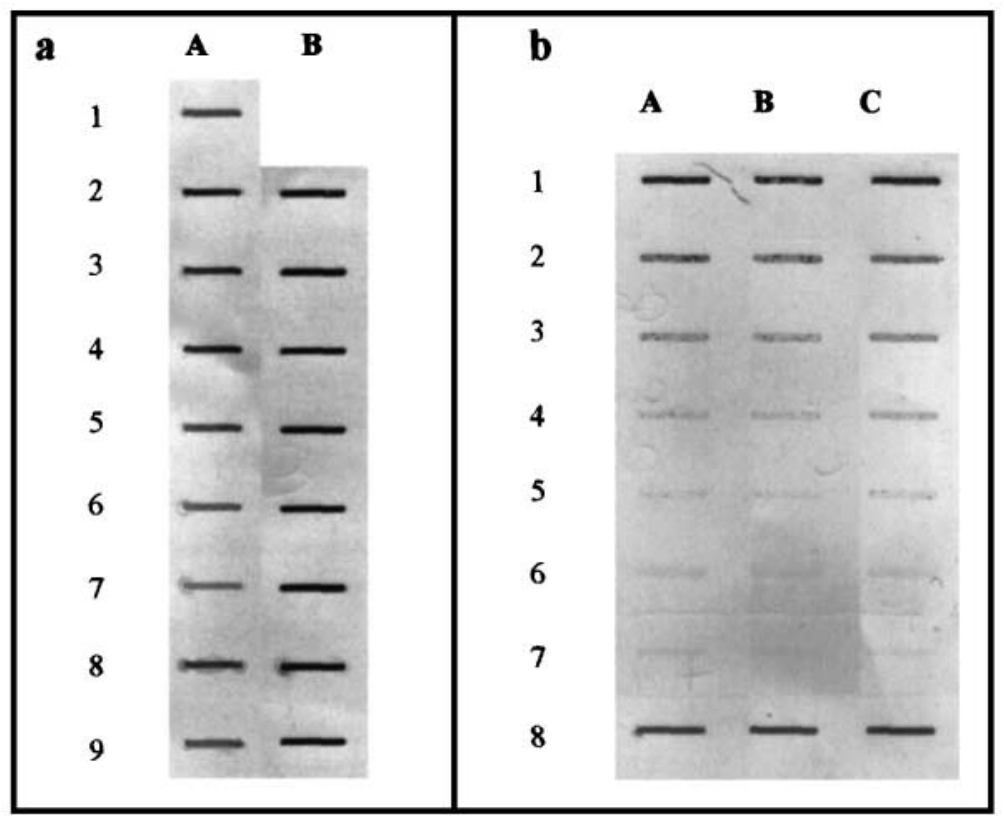

Fig. 2. Binding of haemin to Photobacterium damselae subsp. piscicida protein membrane extracts and purified capsular polysaccharide. (a) Binding of haemin to total (A) and outer (B) membrane protein extracts. Aliquots containing $2 \mu \mathrm{g}$ of total ( $\mathrm{a}$, lane $\mathrm{A})$ and outer $(\mathrm{a}$, lane $\mathrm{B})$ membrane proteins from strains DI $21(2,3)$, B $51(4,5)$, ATCC $29690(6,7)$ and EPOY 8803-II $(8,9)$ cultured under iron-restricted $(2,4,6,8)$ or iron-supplemented $(3,5,7,9)$ conditions were loaded onto the nitrocellulose membrane. Vibrio anguillarum 775 was used as a positive control (1). (b) Binding of haemin by DI 21 purified capsular polysaccharide. Lane A: untreated capsular polysaccharide. Lane B: heat-treated capsular polysaccharide. Lane C: capsular polysaccharide treated with Proteinase K. Rows 1 to 5: decreasing amounts of capsular polysaccharide (30 to $1.815 \mu \mathrm{g}$ ). Row 6: Proteinase K alone. Row 7: Escherichia coli HB101 (negative control). Row 8: V. anguillarum 775 (positive control). Haemin detected with 3,3'-dimethoxybenzidine 


\section{Haemin binding by purified capsular polysaccharide}

Because the presence of a constitutive capsular polysaccharide in the pathogenic Photobacterium damselae subsp. piscicida strains was previously reported (Bonet et al. 1994), we tested the ability of DI 21 capsular polysaccharide to bind haemin. When the dot blot assay was used, purified capsular polysaccharide was observed to bind haemin. Binding was detected when $30,15,7.5$ or $3.75 \mu \mathrm{g}$ of capsular polysaccharide was loaded on the membrane but it was no longer detectable when $1.8 \mu \mathrm{g}$ or less per band was tested (Fig. 2b).

\section{Inhibition assays}

When iron-limited or iron-supplemented bacterial cells were pre-treated with Proteinase $\mathrm{K}$, their ability to bind haemin was greatly reduced compared with that of cells not treated with the enzyme $(p \leq 0.05$, except for the samples collected after $10 \mathrm{~min}$ for which the difference was not significant) (Fig. 3a). The inhibitory effect of Proteinase $\mathrm{K}$ treatment was also ob- served when total membrane proteins were tested for haemin binding in a dot blot assay (Fig. 3b). In contrast, binding of haemin to DI 21 capsular polysaccharide was found to be unaffected by pre-treatment with Proteinase K (Fig. 2b) Heating at $100^{\circ} \mathrm{C}$ for $10 \mathrm{~min}$ did not affect the ability of either total membrane protein extracts (Fig. 3b) or capsular polysaccharide (see Fig. 2b) to bind haemin.

Attempts to analyse the haemin binding by outer membrane proteins using sodium dodecyl sulphate polyacrylamide gel electrophoresis and western blotting were unsuccessful (data not shown), perhaps indicating that the reducing conditions used destroyed the ability of the proteins to bind haemin.

\section{Competitive binding assays}

Preliminary assays showed that Photobacterium damselae subsp. piscicida cells were able to bind protoporphyrin IX and biotinylated bovine haemoglobin (results not shown). Competitive binding assays were performed with strains DI 21, B 51 and ATCC 29690 cultured under iron-limited conditions to investigate whether different haem compounds shared the same binding site or receptor. Similar results were obtained for all these strains and Fig. 4 shows the results for strain DI 21. No inhibition in the binding of haemin was observed when cells of virulent and non-virulent strains were pre-incubated with haemoglobin. Although a marked decrease in the ability to bind haemin was detected in some assays when protoporphyrin IX was used as a competitor, the differences were not statistically significant $(\mathrm{p}>0.05)$.

\section{DISCUSSION}

Haem compounds are known to be an important iron source for many pathogenic bacteria. It has been reported that Photobacterium damselae subsp. piscicida is able to utilise haemin and haemoglobin as the sole iron source in vitro (Magariños et al. 1994).

The present results of the haemin binding assays carried out by the 2 methods described show that whole cells of the 4 strains of Photobacterium damselae subsp. piscicida tested were able to bind the compound. The binding was significantly decreased by pre-treatment of bacterial cells with Pro-
Fig. 3. (a) Binding of haemin by Photobacterium damselae subsp. piscicida DI 21. Cells grown under iron-restricted $(\square)$ or iron-supplemented $(0)$ conditions were incubated with Proteinase $\mathrm{K}$ and subsequently tested for the iron-supplemented $(\bullet)$ conditions were used as controls. (b) Binding of haemin to total protein extracts of P. damselae subsp. piscicida (lane A). Effect of heat treatment (lane B) and Proteinase K (lane C) on the binding activity. Aliquots containing $2 \mu \mathrm{g}$ of protein from strains DI 21, B 51, ATCC 29690 and EPOY 8803-II cultured under iron-restricted (rows 1, 3, 5 and 7) or iron-supplemented (rows 2, 4,6 and 8) conditions were used. Haemin was detected with 3,3'-dimethoxybenzidine. Row 9: Escherichia coli HB101 (negative control). Row 10: Vibrio anguillarum 775 (positive control) 


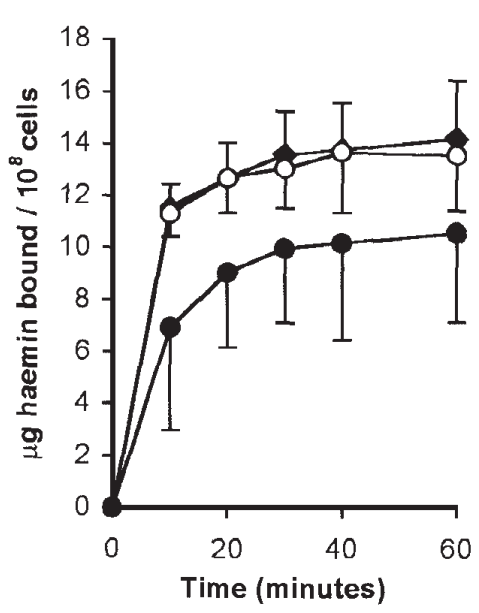

Fig. 4. Competitive binding between protoporphyrin IX or haemoglobin and haemin by Photobacterium damselae subsp. piscicida DI 21 cultured under iron-restricted conditions. Cells were allowed to pre-bind protoporphyrin IX $(\bullet)$ or haemoglobin (O) for $1 \mathrm{~h}$ and the haemin binding was then determined. Cells not pre-incubated with the competitors (•) were used as controls

teinase $\mathrm{K}$, indicating that protein receptors located at the cell surface are involved in the binding of haemin.

It has been suggested that haem acquisition by bacteria might involve a receptor-mediated process with, as an initial step, specific interaction with surface-exposed protein receptors (Lee 1995). Using the dot blot assay, it was found that total membranes, as well as outer membrane proteins, were able to bind haemin. However, for the same amount of protein, stronger binding to the outer membrane proteins than to total membrane protein extracts was seen, indicating that a higher density of haemin receptors is present in the outer membrane fraction. The binding of haemin by Photobacterium damselae subsp. piscicida membrane protein extracts was not affected by heat treatment but was almost completely abolished by Proteinase K treatment. These results suggest that cell surface-associated, heatresistant proteins are mainly responsible for the binding of haemin by $P$. damselae subsp. piscicida.

The occurrence of a residual haemin binding observed after Proteinase K treatment of Photobacterium damselae subsp. piscicida whole cells suggests that, in addition to protein-receptors, some other, proteaseresistant, component(s) could also bind haemin. Using the dot blot assay, it was shown that $P$. damselae subsp. piscicida capsular polysaccharide was able to bind haemin but with a much lower affinity than the binding by membrane proteins. This suggests that capsular polysaccharide could have contributed to the haemin binding reported in this study. We cannot rule out the possibility that some other protease resistant bacterial components, such as lipopolysaccharide, may participate in the haemin binding of $P$. damselae subsp. pisci- cida, as has been reported for other bacterial species (Grenier et al. 1997).

Some bacterial pathogens, such as Vibrio anguillarum, V. vulnificus, Photobacterium damselae subsp. damselae and Aeromonas salmonicida, possess surface receptors for haemin and haemoglobin, the expression of which is not regulated by iron (Fouz et al. 1994, Hirst et al. 1994, Fouz et al. 1996, Mazoy \& Lemos 1996, Mazoy et al. 1996). In contrast, other microorganisms, such as Neisseria gonorrhoeae, N. meningitidis, Haemophilus influenzae and Yersinia enterocolitica, express iron-regulated haemin receptors (Lee 1992a,b, 1994, Stojiljkovic \& Hantke 1992). In the present study, using 2 different techniques, it was found that the binding of haemin by whole cells of the $P$. damselae subsp. piscicida virulent strains DI 21 and B 51 and non-virulent strain ATCC 29690 cells was greatly increased under iron-limited conditions. In contrast, iron limitation did not significantly enhance the binding of haemin by the non-pathogenic EPOY 8803-II cells. These differences were not due to differences in viability because colony forming units (CFU) counts of virulent and avirulent strains cultured with or without added iron were not different (data not shown). Instead, those results could be due to the existence, in all the strains tested, of constitutive receptors for haemin and additional inducible haemin receptors in DI 21, B 51 and ATCC 29690 but not in the EPOY 8803-II cells. However, for reasons not yet understood, no differences were detected when binding of haemin by membrane protein extracts from iron-limited or iron-supplemented bacteria was compared. One possible explanation for this finding is that the inducible receptors, but not the constitutive ones, are sensitive to the sonication treatment used in the membrane isolation protocol.

The presence of efficient iron uptake systems has been considered an important virulence determinant of several bacterial pathogens (Payne 1993). Both Photobacterium damselae subsp. piscicida virulent strains tested in this study were able to increase the binding of haemin in response to iron limitation. The non-pathogenic strain ATCC 29690 behaved like the virulent ones with respect to haemin binding, while the other non-virulent strain (EPOY 8803-II) was not able to increase the binding of haemin when cultured under iron-limited conditions. These results are not surprising, as virulence almost never results from the presence of only one component and/or mechanism, being rather a multifactorial process. It was previously reported that the amount of capsular polysaccharide expressed by $P$. damselae subsp. piscicida cells is dependent on iron availability, being higher in ironsupplemented cells than in iron-limited ones (Magariños et al. 1996a, do Vale et al. 2001). This observation suggests that the $P$. damselae subsp. piscicida capsular 
polysaccharide would play a minor role in the binding of haemin. The results of the present study, showing that the virulent and constitutively capsulated strain DI 21 (Magariños et al. 1996a, do Vale et al. 2001) and the non-virulent and non-capsulated strain ATCC 29690 (Magariños et al. 1996a) behaved very similarly with respect to the binding of haemin, also support this suggestion. Surface outer membrane protein receptors would therefore be responsible for most of the haeminbinding ability of these bacteria. Such binding may be favoured by a reduction in the amount of capsular polysaccharide.

The results of the competitive binding studies suggest that binding of haemin and protoporphyrin IX, but not of haemoglobin, by Photobacterium damselae subsp. piscicida cells is mediated by some common receptor(s), although the existence of additional specific receptors for each of the compounds cannot be excluded.

In conclusion, the present work shows that constitutive as well as inducible mechanisms of haemin binding occur in Photobacterium damselae subsp. piscicida. These mechanisms would rely mainly upon the direct interaction between the haemin molecules and surface-exposed outer membrane protein receptors. Studies on the characterisation of proteins or genes involved in the uptake of haemin by $P$. damselae subsp. piscicida are in progress.

Acknowledgements. We are grateful to M. T. Silva for helpful discussions and for reviewing the manuscript. This work was supported by a grant from the Portuguese PRAXIS XXI Programme (PRAXIS XXI/BD/11038/97) and grants PB970546 from Dirección General de Enseñanza Superior e Investigación Científica (Ministerio de Educación y Ciencia) and AGL2000-0492 from the Dirección General de Investigación (Ministerio de Ciencia y Tecnología), Spain.

\section{LITERATURE CITED}

Bonet R, Magarinos B, Romalde JL, Simon-Pujol MD, Toranzo AE, Congregado F (1994) Capsular polysaccharide expressed by Pasteurella piscicida grown in vitro. FEMS Microbiol Lett 124:285-289

Bullen JJ (1981) The significance of iron in infection. Rev Infect Dis 3:1127-1138

do Vale A, Ellis AE, Silva MT (2001) Electron microscopic evidence that expression of capsular polysaccharide by Photobacterium damselae subsp. piscicida is dependent on iron availability and growth phase. Dis Aquat Org $44: 237-240$

Fouz B, Toranzo AE, Biosca EG, Mazoy R, Amaro C (1994) Role of iron in the pathogenicity of Vibrio damsela for fish and mammals. FEMS Microbiol Lett 121:181-188

Fouz B, Mazoy R, Lemos ML, del Olmo MJ, Amaro C (1996) Utilization of hemin and hemoglobin by Vibrio vulnificus biotype 2. Appl Environ Microbiol 62:2806-2810

Grenier D, Leduc A, Mayrand D (1997) Interaction between
Actinobacillus actinomycetemcomitans lipopolysaccharides and human hemoglobin. FEMS Microbiol Lett 151: $77-81$

Griffiths E (1987) The iron uptake systems of pathogenic bacteria. In: Bullen JJ, Griffiths E (eds) Iron and infection. Molecular, physiological and clinical aspects. John Wiley \& Sons, Chichester, p 69-137

Hirst ID, Hastings TS, Ellis AE (1994) Utilization of haem compounds by Aeromonas salmonicida. J Fish Dis 17:365-373

Kitao T (1993) Pasteurellosis. In: Inglis V, Roberts RJ, Bromage NR (eds) Bacterial diseases of fish. Blackwell Science, Oxford, p 159-165

Lee BC (1992a) Isolation of an outer membrane hemin-binding protein of Haemophilus influenzae type b. Infect Immun 60:810-816

Lee BC (1992b) Isolation of haemin-binding proteins of Neisseria gonorrhoeae. J Med Microbiol 36:121-127

Lee BC (1994) Isolation and characterization of the haeminbinding proteins from Neisseria meningitidis. Microbiology 140:1473-1480

Lee BC (1995) Quelling the red menace: haem capture by bacteria. Mol Microbiol 18:383-390

Magariños B, Romalde JL, Lemos ML, Barja JL, Toranzo AE (1994) Iron uptake by Pasteurella piscicida and its role in pathogenicity for fish. Appl Environ Microbiol 60: 2990-2998

Magariños B, Bonet R, Romalde JL, Martinez MJ, Congregado F, Toranzo AE (1996a) Influence of the capsular layer on the virulence of Pasteurella piscicida for fish. Microb Pathog 21:289-297

Magariños B, Toranzo AE, Romalde JL (1996b) Phenotypic and pathobiological characteristics of Pasteurella piscicida. Annu Rev Fish Dis 6:41-46

Martínez JL, Delgado-Iribarren A, Baquero F (1990) Mechanisms of iron acquisition and bacterial virulence. FEMS Microbiol Rev 6:45-56

Mazoy R, Lemos ML (1996) Identification of heme-binding proteins in the cell membranes of Vibrio anguillarum. FEMS Microbiol Lett 135:265-270

Mazoy R, Vazquez F, Lemos ML (1996) Isolation of hemebinding proteins from Vibrio anguillarum using affinity chromatography. FEMS Microbiol Lett 141:19-23

Moeck GS, Coulton JW (1998) TonB-dependent iron acquisition: mechanisms of siderophore-mediated active transport. Mol Microbiol 28:675-681

Otto BR, Verweij-van Vught AM, MacLaren DM (1992) Transferrins and heme-compounds as iron sources for pathogenic bacteria. Crit Rev Microbiol 18:217-233

Payne SM (1993) Iron acquisition in microbial pathogenesis. Trends Microbiol 1:66-69

Romalde JL, Magariños B (1997) Immunization with bacterial antigens: pasteurellosis. In: Gudding R, Lillehaug A, Midtlyng PJ, Brown F (eds) Fish vaccinology. Developments in biological standardization. Karger, Basel, p 167-177

Schryvers AB, Stojiljkovic I (1999) Iron acquisition systems in the pathogenic Neisseria. Mol Microbiol 32:1117-1123

Stojiljkovic I, Hantke K (1992) Hemin uptake system of Yersinia enterocolitica: similarities with other TonBdependent systems in gram-negative bacteria. Embo J 11: $4359-4367$

Toranzo AE, Barja JL, Potter SA, Colwell RR, Hetrick FM, Crosa JH (1983) Molecular factors associated with virulence of marine vibrios isolated from striped bass in Chesapeake Bay. Infect Immun 39:1220-1227

Weinberg ED (1993) The iron-withholding defense system. ASM News 59:559-562

Submitted: June 14, 2001; Accepted: August 20, 2001

Proofs received from author(s): February 1, 2002 